\title{
Maria Mendel, Wiesław Theiss (red.), Pamięć i miejsce. Perspektywa społeczno-edukacyjna, Wydawnictwo Uniwersytetu Gdańskiego, Gdańsk 2019, ss. 399
}

W czasach niepewności i konfliktów związanych z kryzysem demokracji liberalnej, globalizacją, migracjami, nierównościami, wykluczeniem społecznym grup i jednostek szczególnego znaczenia nabiera to, co zakorzenione, oswojone, co pozwala budować indywidualną i społeczną tożsamość, tworzyć wspólną przestrzeń ludzką i obywatelską.

Ważnymi kategoriami będącymi przedmiotem współczesnych badań są „pamięć” i „miejsce”. Memory studies są obecnie istotną częścią refleksji w humanistyce, a współczesne przemiany pamięci analizowane są na różnych poziomach: lokalnym, narodowym, regionalnym (Assmann, 2013). Pamięć kulturowa jest traktowana transdyscyplinarnie z uwzględnieniem perspektywy socjologii, psychologii, antropologii, kulturoznawstwa, politologii i innych (Connerton, 2012). Obecne, w opiniach badaczy, w społeczeństwach współczesnych sposoby pamiętania i mity narodowe nadal mają wielką moc definiowania tożsamości i kształtowania ludzkich losów oraz prowokowania konfliktów (Smith, 2005), ale pamięć może stać się także przestrzenią dialogu. Przy czym dokonuje się, jak ujął to francuski historyk Pierre Nora, „demokratyzacja pamięci” (Nora, 2001, s. 41), czyli odzyskiwanie prawa do własnej wizji historii przez te grupy, które dotąd jej nie mogły wyrażać.

„Pedagogika miejsca”, „krytyczna pedagogika miejsca” jest traktowana jako remedium przeciw niezrównoważonemu rozwojowi, godzącemu w dobro ludzi,

1 Anna Zielińska, Wydział Pedagogiczny, Uniwersytet Warszawski, Polska, e-mail: azielinska@ uw.edu.pl. 
ich dziedzictwa kulturowego i przyrody (Graham, 2007). W Polsce w tym nurcie z wybitną monografią o mieście i szkole sytuuje się Maria Mendel (Mendel, 2017).

Interesującą próbą wspólnego badania miejsca i pamięci ujętych w kategorii wyrażających ich związek i nazwanej pamięciomiejscem jest monografia napisana przez pedagogów, socjologów, historyków, kulturoznawców, artystów, muzealników, badaczy polskich i zagranicznych: Pamięć i miejsce. Perspektywa społeczno-edukacyjna, pod redakcją Marii Mendel i Wiesława Theissa. Wspólna publikacja badaczy reprezentujących tak różne dyscypliny i punkty widzenia jest interesującym pomysłem i jednocześnie wielką szansą dla czytelnika spojrzenia szerzej i głębiej na wzajemne relacje miejsca i pamięci. Jednocześnie tak szeroka koncepcja i potrzeba połączenia różnych perspektyw badawczych stanowi wielkie wyzwanie dla redaktorów monografii i autorów dzieła. M. Mendel i W. Theiss dobrze poradzili sobie z tym wyzwaniem, stwarzając bardzo interesujące dla czytelnika, oryginalne dzieło. Redaktorzy monografii i autorzy tego projektu badawczego sytuują swoją pracę przede wszystkim w obszarze pedagogiki społecznej jako „zasilającą” jej teorię, choć zakres refleksji i poruszane w nim zagadnienia wykraczają poza obszar pedagogiki - w rejony badań z zakresu socjologii, antropologii, historii i innych dyscyplin.

Redaktorzy podkreślają, że spoiwem łączącym pamięciomiejsce jako kategorię teoretyczną były zawarte w różnych tekstach wątki, wskazujące wspólną obecność oraz „pracę” pamięci i miejsca, przebiegającą w jednostkowym i społecznym podmiocie. Kontekstem, w którym powstał projekt, była - jak ujmują to jego autorzy „kondycja rzeczywistości, w której żyjemy, i której język adekwatnego opisu przez lata tworzył Zygmunt Bauman” (Mendel, Theiss 2019, s. 11). Narzędziem, którym posługują się - jest wprowadzona przez Baumana metafora retrotopia. Autorzy wyraźnie więc sytuują swój projekt w kontrze do neoliberalnej bezalternatywności w wyborze modelu rozwoju, manipulowania czasem, ahistoryzmu, w rozumieniu Timothy'ego Snydera (2017).

Przedstawione w książce analizy i projekty badawcze dotyczą różnych przedziałów czasowych i okresów historii. Można usytuować je na osi czasu - odległego, związanego z życiem poprzednich pokoleń, który obecny i pamiętany we współczesności tworzy pamięciomiejsca, i na drugim krańcu kontinuum, czasu - bliskiego, a więc związanego ze współczesnymi wydarzeniami, który skutkuje pamięciomiejscami in statu nascendi. W monografii pojawiają się na przykład pamięciomiejsca sięgające czasów wojny i tragicznych przeżyć obozowych, łączące historię wyrażaną przez eksponaty muzealne i narracje więźniów ze współczesnym życiem tych miejsc, które stają się silnie zabarwionym emocjonalnie przeżyciem egzystencjalnym, przybliżającym współczesnym ludziom doświadczenie więźniów 
(Malinowska, 2019). Na drugim krańcu osi czasu mamy pamięciomiejsca współczesne, powstające na naszych oczach. Takim przykładem jest budowanie pamięci o Rewolucji Godności 2014 w społeczności Sambora i Lwowa (Bykowski, 2019), która wspiera postawy obywatelskie i poczucie wspólnotowości.

Znaczącą rolę zajmuje opis miejsc rodzinnych i ich znaczenia dla zrozumienia siebie i świata, poczucia tożsamości i godności narratora, budowania mikrohistorii. Jest to część monografii szczególnie interesująca dla pedagogów. Na przeciwległym krańcu sytuuje się opis nie-miejsc, zimnych i wrogich.

Pamięciomiejscom rodzinnym poświęcony jest rozdział „Pamięć i miejsce rodzinne”. Te rodzinne mikrohistorie wplatające się w szerszy kontekst historyczny i przedstawiający go z perspektywy jednostki i grupy rodzinnej charakteryzują się dużą różnorodnością i odmiennością doświadczeń ich autorów. Można tu wskazać odzyskiwanie poczucia tożsamości i więzi z historią rodziny przez zamieszkałe w Izraelu dzieci, których rodzice przeżyli Holokaust, z jednoczesnym przedstawieniem procesu zapominania o doświadczeniach zagłady, które miało miejsce aż do lat 60. XX wieku. Powolna rekonstrukcja historii życia codziennego swoich przodków, ich lat szkolnych, pracy, sposobów bytowania przed zagładą była niezwykle silnym, zmieniającym stosunek do świata i historii doświadczeniem „drugiego” pokolenia (Gilad, 2019).

Odzyskiwania pamięci dotyczył także projekt badawczy, którego celem było otworzenie przekazów rodzinnych w rodzinach wileńskich przesiedlonych do Gdańska, który przeprowadziła Alicja Zbierzchowska (2019). Analiza narracji odnoszącej się do kształtowania się pamięci rodziny pozwoliła pokazać ten przekaz z dwóch perspektyw: przeszłej i teraźniejszej. Badania z jednej strony umożliwiły poznanie sposobów przekazywania historii rodziny przez przodków, z drugiej strony pozwoliły poznać stosunek badanych osób do pamięci rodziny i świadomości własnej roli w jej tworzeniu. W tym projekcie także widzimy proces „zapominania”, a raczej manipulowania pamięcią. Rodzice ukrywali przed dziećmi traumatyczną przeszłość, wiele kwestii z przyczyn bądź to politycznych, bądź obyczajowych pozostawało tematami tabu. Dopiero po latach, dzięki własnej dociekliwości, dorosłe już dzieci przesiedleńców poznawały swoją (i swojej rodziny) historię. Dzieje badanych gdańszczan pochodzenia wileńskiego ukazują, jak pamięć jednostek, ale również społeczności i narodów może być fragmentaryczna, jak przeplata się z „niepamięcią” i pamięcią zmanipulowaną. Wśród badanych znacznie lepiej rozbudowana jest pamięć nowsza, dotycząca udziału w odbudowie Gdańska i doświadczenia życia w tym mieście. W związku z tym projektem autorka formułuje interesującą propozycję dzielenia się pamięcią osobistą na potrzeby społeczności lokalnej. Propozycja dobrze wpisuje się w ogólne 
przesłanie monografii, ukazując, jak tworzą się pamięciomiejsca gdańszczan pochodzących z Wilna.

Inną ciekawą odsłoną budowania historii rodzinnej i refleksji nad nadawaniem indywidualnego znaczenia rodzinnej pamięci jest projekt dotyczący badań prowadzonych wśród studentek z Białegostoku. Celem projektu było nie tylko poznanie, jak pamięć rodzinna funkcjonuje w świadomości badanych, ale także, jakie znaczenie dla młodych ma pamięć o przeszłości, jak jest przekazywana i kultywowana (Łaguna-Raszkiewicz, 2019). Autorka podjęła próbę wykreowania „historii przeżytej”, dokonując hermeneutycznej interpretacji dialogu pokoleń w celu stworzenia obrazu rodzinnej narracji o przeszłości.

Najpełniej tytułowi części monografii „, Pamięć i miejsce rodzinne” odpowiada treść rozdziału „Miejsce, przestrzeń i czas w historii rodziny” Tadeusza Pilcha (2019) Ten tekst wyróżnia się także ciekawym zamysłem badawczym: autor dokonuje bowiem rekonstrukcji historii własnej rodziny. Opisuje w niezwykle interesujący sposób swoich przodków, ich dzieje, ich uwikłania w wydarzenia historyczne i tragiczne nieraz losy. W tej narracji jest też miejsce dla zdjęć rodzinnych - belki z rodzinnego domu, map z historiami podróży członków rodziny. Historia rodziny Pilchów odzwierciedla dzieje społeczne, można z niej odczytać, a przede wszystkim pełniej doświadczyć i niemal namacalnie poczuć ogrom zmian w życiu naszego społeczeństwa. Ostatnie zdania dotyczące losów młodego pokolenia - dzieci autora, obywateli świata, którzy wszędzie się dobrze czują i wszędzie mogą mieszkać, którzy podróżują jako turyści w miejsca, gdzie ich przodkowie wyjeżdżali „za chlebem”, wyganiani z rodzinnego domu przez biedę - jest bardzo szczególnym, bo osobistym świadectwem historii społecznej. Pokazuje także na konkretnym przykładzie zjawisko globalizacji. W ciągu ponad 160 lat lokalny świat rodziny, który ograniczał się do niewielkiej wioski i okolicy, stał się światem globalnym.

Rodzina, pamięć rodzinna, miejsce rodzinne kojarzą się z czymś bliskim, oswojonym. Opozycyjne przeżycia przewodzą na myśl pogranicze kultur, miejsce, gdzie „swoi” spotykają się z „obcymi”, a w szczególności nie-miejscem (non-lieux), terminem wprowadzonym przez francuskiego autora Marca Auge (2012). Nie-miejsce do nikogo nie przynależy. Miejsce jest znajome, nasycone tożsamością, historyczne, nie-miejsce jest jego przeciwieństwem. Nie-miejsca są znakiem naszych czasów, to na przykład samoloty, pociągi, dworce, sieci hotelowe, sklepy wielkopowierzchniowe.

Pogranicze jest szczególnym pamięciomiejscem. Jolanta Muszyńska, autorka rozdziału „Pogranicze (w) pamięci. Zapominanie”, powołując się na Znanieckiego i Castellsa, zwraca uwagę, że „przestrzeń nabiera znaczenia miejsca, w sytuacji gdy 
zostanie naznaczona wartościami, kulturą” (Muszyńska, 2019, s. 208). Na pograniczu mogą też występować nie-miejsca. Cechą miejsca jest stałość, a przestrzeni ruch i zmienność. Miejsca pogranicza są „swoje” lub „nieswoje” dla różnych osób działających w jego przestrzeni. Mieszkańcy żyją w grupie zróżnicowanej kulturowo. Badanie autorki dotyczy zapominania jako cechy charakterystycznej pogranicza. W pamięci zbiorowej zachowywane są zdarzenia ważne dla danej społeczności, wypierane ze świadomości i zapominane są te, które są dla tej społeczności niewygodne. Jolanta Muszyńska zwraca uwagę na będącą przejawem selektywnego zapominania „amnezję strukturalną”, która na pograniczu pełni funkcję legitymizacji dominującej roli grupy większościowej, czyli na przykład Polaków wobec mniejszości białoruskiej czy litewskiej i podaje ciekawe przykłady takiej amnezji przejawiającej się w likwidacji pomników, nazw ulic, wypieraniu z pamięci konfliktów, a nawet zbrodni. Autorka zwraca uwagę na szczególną cechę pamięci pogranicza - to pamięć, która koncentruje się na zmaganiu państw, narodów i kultur, a pomija codzienne życie mieszkańców, ich indywidualną pamięć, która tworzy pamięć miejsca. Natomiast pamięć pogranicza wiążę się z zapominaniem i przez to zmienianiem tożsamości pogranicza. Praca autorki stanowi apel o pamięć transkulturową, odrzucającą koncepcję pamięci zbiorowej jako pamięci narodowej dominującej grupy, która implikuje konfliktowy charakter pamięci wewnątrz kraju i w relacjach z sąsiadami. W dzisiejszych czasach narastających nacjonalizmów i używania historii jako narzędzia do prowadzenia polityki to przesłanie wydaje się bardzo aktualne.

Szczególnie zimne i wrogie są wspomniane wcześniej nie-miejsca. Patrycja Terciak (2019) przywołuje miejsce porzucone, omijane, wyrzucone z pamięci, jakim jest teren na granicy „getta Litzmannstand”. Autorka przyjmuje założenie, że istota miejsca jest następstwem relacji podmiotu wobec przestrzeni. Miejsce jest ukonstytuowane w przeżyciu i uzyskuje od niego bytową niezależność, jako byt intencjonalny poprzedza nasze doznanie i doświadczenie. Powołując się na Marca Auge, autorka zauważa, że „zależność i możliwość zaistnienia nie-miejsca rozpatrywana jest zawsze względem miejsca” (Terciak, 2019, s. 229). Nie-miejsca są nikomu niepotrzebne, są marginalizowane przez społeczność i wypierane z pamięci, jeśli są miejscami traumatycznymi. Patrycja Terciak dokonuje ciekawego zabiegu, powołując się na G. Didi-Hubermana, który zaproponował zastąpienie terminu nie-miejsce pamięci pojęciem miejsce mimo wszystko (Terciak, 2019, s. 232) czyli miejsca wymyślonego dla ratowania siebie, pamięci, nadziei. Takie podejście autorka wykorzystała w swoim projekcie akcji miejskiej „Rysunek z pamięci” i w pracy z ocalałymi z Łódzkiego Getta. Zaprojektowała akcję miejską, której celem było łączenie działań badawczych, dokumentacyjnych, artystycz- 
nych odwołujących się do przeszłości i dnia dzisiejszego miasta Łodzi. Przez rok pracowała z ocalałymi. Działając w obszarze nie-miejsca (Dom na ul. Brackiej, na pograniczu getta), spowodowała, że stał się miejscem mimo wszystko. Podjęte działanie jest ciekawym przykładem oswajania przestrzeni niepotrzebnej, wrogiej, odrzucanej.

Uczenie i oswajanie miejsc pamięci (niepamięci) było także celem przedsięwzięcia badawczo-dydaktycznego Kingi Majchrzak-Ptak (2019), która przez projekt oparty na metodologii badania w działaniu, wspartej analizą i interpretacją danych zgromadzonych za pomocą obserwacji uczestniczącej i samoobserwacji, wywiadów na podstawie zdjęć, przeszukania źródeł wtórnych, podjęła wspólnie ze studentami poszukiwanie ich miejsc pamięci (niepamięci) na Uniwersytecie Mikołaja Kopernika w Toruniu. Autorce udało się zidentyfikować proces tworzenia się tożsamości badanych na poziomach: rodziny, społeczności lokalnej i kraju/ narodu.

Ciekawą perspektywę analizy pamięciomiejsca przyjęto w części zatytułowanej „Gościnność pamięci i miejsca”. W kulturze i życiu potocznym gościnność sytuuje się w sferze obyczajowości. Marcin Boryczko odwołuje się do Emmanuela Kanta, który „naturalne prawo gościnności” utożsamia z prawem natury (Boryczko, 2019, s. 265). Autor rozpatruje gościnność w kontekście nasilających się migracji i kryzysu uchodźczego. Zwraca uwagę, że gościnność staje się w coraz większym stopniu uniwersalną formułą współistnienia zróżnicowanych wspólnot, natomiast rzadko jest przedmiotem refleksji. Konieczność przedefiniowania kategorii gościnności wynika z tego, że „nabrała ona charakteru etycznego, realizuje się w wymiarze przestrzennym oraz współuczestniczy w wytwarzaniu pamięci” (Boryczko, 2019, s. 267). Szczególnie interesująca jest część eseju, w której autor rozpatruje „gościnność jako wytwarzanie i rekonstruowania pamięci”. Zauważa, że pamięcią, a szczególnie krzywdami, które „naszym” wyrządzili „obcy”, karmi się każdy nacjonalizm i fundamentalizm, doprowadzając do „wojny narracyjnej”. Pyta więc o możliwość zastąpienia pamięci krzywdy innym rodzajem pamięci i poszukiwaniem „pęknięć i sprzeczności w monolitycznych, zuniformizowanych i znatywizowanych tożsamościach grupowych” (Boryczko, 2019, s. 276). Podaje także intersujące rodzime przykłady praktyk niespójności, widzianych z perspektywy narodowej wersji tożsamości oraz pamięci gościnności i pokojowego współżycia, które mogą być alternatywą dla „wojen narracyjnych”.

Rozwinięciem tych wątków jest projekt badawczy prowadzony wśród osób ubiegających się o azyl i uchodźców w Gdańsku (Jaworska, Alieva, 2019) Uchodźcy - „ludzie bez miejsca”, ale z pamięcią miejsca utraconego, „zawieszeni pomiędzy utraconą ojczyzną a nieznaną, nieustaloną i nieoswojoną obczyzną" 
(Jaworska, Alieva, 2019, s. 285), a także pomiędzy pamięcią przeszłości a trudną do przewidzenia przyszłością, są w szczególnym położeniu, silnie przeżywają doświadczenie przebywania w nie-miejscu i nie-czasie. Trudności uchodźców potęgują złe warunki bytowe, bezdomność, a także nasilająca się w ostatnich latach, w naszym społeczeństwie niechęć, a nawet wrogość wobec uchodźców, są oni często traktowani jako „społeczność podejrzana” (Jaworska, Alieva, 2019, s. 290). Ciekawym sposobem na przezwyciężenie tego kręgu niechęci i niezrozumienia był próba stworzenia przez przymusowych imigrantów domu, opartego o zasady samoorganizacji i samopomocy, który miał stać się ich miejscem. Działalność społeczna i edukacyjna domu odbywała się z poszanowaniem tradycji kulturowych i wartości szanowanych przez mieszkańców, dotyczących sposobów spędzania czasu, obchodzenia świąt, organizacji pomocy potrzebującym. Inspiracją do stworzenia takiego domu była wizja Gdańska jako „wspólnego pokoju” (Jaworska, Alieva, 2019, s. 298; za: Mendel, 2015) i „budowanie mostów” (Jaworska, Alieva, 2019, s. 298; za: Czyżewski, 2012). Nazwa Dom Międzykulturowy wyraża wewnętrzną organizację i model relacji ze społecznością miasta. Celem przedsięwzięcia było oswajanie różnorodności, pogłębienie zrozumienia i podejmowanie wspólnego działania przez grupy narażone na podziały, uprzedzenia, lęki. Projekt jest praktyczną realizacją postulowanej w innych częściach monografii gościnności i próbą znalezienia przez migrantów swojego miejsca wśród społeczności goszczącej, a dom staje się miejscem odzyskiwania podmiotowości i sprawczości przez społeczność przebywająca dotąd w nie-miejscu.

W monografii pojawiają się jeszcze dwie ciekawe perspektywy pamięciomiejsca. Jedna dotyczy architektury, która może pełnić funkcję „pasa transmisyjnego” dla niektórych form pamięci społecznej. „Pamięć architektury będzie zasobem określonych treści komunikowanych do danej zbiorowości poprzez fizyczne jej cechy” (Michałowski, 2019, s. 327). Inaczej te treści będzie kumulowała i przekazywała architektura mieszkaniowa, a inaczej wielkie obiekty publiczne. Niekiedy obiekty architektoniczne mogą ogniskować debatę o polskiej tożsamości, jak to miało miejsce w przypadku niemieckiej „Hali Stulecia” i polskiej „Hali Ludowej” we Wrocławiu. Wpisywanie tego obiektu na listę światowego dziedzictwa UCESCO wywołało debatę o niemieckiej przeszłości miasta i definiowania polskości przez konkurujące koncepcje pamięci historycznej i zbiorowej tożsamości (Cervinkova, Golden, 2019).

Druga perspektywa dotyczy lasu jako pamięciomiejsca. Przykładem jest przywołany w monografii, znaczący dla lokalnej społeczności, Kamieniecki Las. Stanowi część pamięci indywidualnej i zbiorowej, jest miejscem „osobnym, oderwanym, odizolowanym” (Sass, 2019, s. 304). Granice i przynależności państwowe 
zmieniały się, a Kamieniecki Las zawsze stanowił dla mieszkańców miejsce „mikrohistoryczne”. Był miejscem działań zbrojnych i działalności gospodarczej, inspirował poetów i innych twórców, w tym współczesnych uczestników projektu „Stolemowe Drzewo”, którzy w ramach laboratoriów: kreacji animacji, wizualnym, dźwięku, filmowym próbowali nadać temu, co lokalne, wymiar uniwersalny, odwołując się do tolerancji, otwartości, dialogu, dobra wspólnego.

Podsumowując, można powiedzieć, że tak szerokie spojrzenie na związek pamięci i miejsca, wyrażonego przez kategorię pamięciomiejsca, łączące różne perspektywy badawcze pedagogów, kulturoznawców, artystów, socjologów oraz innych badaczy i twórców, a także analizowanie pamięciomiejsc w kontekstach, w których możemy dostrzec pewne opozycje, np. czasu odległego wpisującego się w życie poprzednich pokoleń, często zmanipulowanego i odzyskiwanego po latach, i czasu obecnie przeżywanego, który tworzy nowe pamięciomiejsca: pamięciomiejsc rodzinnych, ciepłych, oswojonych i zimnych, obcych nie-miejsc, pamięciomiejsc tworzonych przez wytwory ludzkiej kultury, np. architekturę i tych, które powstają w symbiozie dzieła natury - lasu i zmieniającego go człowieka, jest bardzo intersującym i wzbogacającym dzieło podejściem.

Monografia Pamięć i miejsce. Perspektywa społeczno-edukacyjna pod redakcją Marii Mendel i Wiesława Theissa jest ważna ze względu na oryginalne podejście do analizowanych zagadnień, twórcze wykorzystanie kategorii pamięciomiejsca i co za tym idzie - ważny wkład w rozwój pedagogiki i nowych kierunków dyskursu pedagogiki z innymi dyscyplinami, ale nie wyczerpuje to jej znaczenia. Wysoko należy ocenić także jej głębokie przesłanie humanistyczne związane z etyką gościnności, tolerancji, otwarcia na innego, pokonywania „wojen narracyjnych”. Te wartości możemy dostrzec we wszystkich częściach monografii, u wszystkich autorów. Dzieło M. Mendel i W. Theissa stanowi więc ważny głos w debacie społecznej w czasach narastających populizmu, wrogości, odrzucania „Innych”.

\section{Bibliografia}

Auge, M. (2012). Nie-miejsca. Wprowadzenie do antropologii hipernowoczesności. Warszawa: Państwowe Wydawnictwo Naukowe.

Assmann, A.(2013). Między historiq a pamięciq. Antologia. Warszawa: Wydawnictwa Uniwersytetu Warszawskiego.

Boryczko, M. (2019). O gościnności. Od etyki do pamięci miejsca. W: M. Mendel, W. Theiss (red.), Pamięć i miejsce. Perspektywa społeczno-edukacyjna (s. 265-280). Gdańsk: Wydawnictwo Uniwersytetu Gdańskiego.

Bykowski, P. (2019). Pamięć i jej wpływ na kształtowanie się kapitału społecznego w świetle wydarzeń Rewolucji Godności na Ukrainie w 2014 roku. W: M. Mendel, 
W. Theiss (red.), Pamięć i miejsce. Perspektywa społeczno-edukacyjna (s. 75-91). Gdańsk: Wydawnictwo Uniwersytetu Gdańskiego.

Cervinkova, H., Golden, J.D. (2019). Wrocławska Hala Stulecia - zmienność historycznej pamięci i tożsamości w kulturowym krajobrazie miasta. W: M. Mendel, W. Theiss (red.), Pamięć i miejsce. Perspektywa społeczno-edukacyjna (s. 341-356). Gdańsk: Wydawnictwo Uniwersytetu Gdańskiego.

Connerton, P. (2012). Jak społeczeństwa pamiętajq. Warszawa: Wydawnictwa Uniwersytetu Warszawskiego.

Gilad, B. (2019). Dokumenty rodzinne i pamięć drugiego pokolenia. W: M. Mendel, W. Theiss (red.), Pamięć i miejsce. Perspektywa społeczno-edukacyjna (s. 107-130). Gdańsk: Wydawnictwo Uniwersytetu Gdańskiego.

Graham, M.A. (2007). Art, Ecology and Art Education: Locating Art Education in a Critical Place-Based Pedagogy. Studies in Art Education, 4(48), s. 375-391.

Jaworska, D., Alieva, K. (2019). Uchodźcy ludzie bez miejsca. Pamięć i miejsce w narracjach przymusowych imigrantów. W: M. Mendel, W. Theiss (red.), Pamięć i miejsce. Perspektywa społeczno-edukacyjna (s. 281-305). Gdańsk: Wydawnictwo Uniwersytetu Gdańskiego.

Łaguna-Raszkiewicz, K. (2019). Pamięć rodzinna - budowanie mikrohistorii. W: M. Mendel, W. Theiss (red.), Pamięć i miejsce. Perspektywa społeczno-edukacyjna (s. 163-184). Gdańsk: Wydawnictwo Uniwersytetu Gdańskiego.

Majchrzak-Ptak, K. (2019). Proces uczenia się własnych miejsc (pamięci) w świetle projektu „Studenci wobec miejsc (nie)pamięci UMK. W: M. Mendel, W. Theiss (red.), Pamięć i miejsce. Perspektywa społeczno-edukacyjna (s. 243-262). Gdańsk: Wydawnictwo Uniwersytetu Gdańskiego.

Malinowska, E. (2019). Człowiek w przestrzeni tragedii obozu. Nowa wystawa główna w Muzeum Stutthof w Sztutowie. W: M. Mendel, W. Theiss (red.), Pamięć i miejsce. Perspektywa społeczno-edukacyjna (s. 55-73). Gdańsk: Wydawnictwo Uniwersytetu Gdańskiego.

Mendel, M. (2017). Pedagogia miejsca wspólnego. Miasto i szkoła. Gdańsk: Wydawnictwo Naukowe Katedra.

Michałowski, L. (2019). Dwie pamięci architektury. W: M. Mendel, W. Theiss (red.), Pamięć i miejsce. Perspektywa społeczno-edukacyjna (s. 327-339). Gdańsk: Wydawnictwo Uniwersytetu Gdańskiego.

Muszyńska, J. (2019). Pogranicze (w) pamięci. Zapominanie. W: M. Mendel, W. Theiss (red.), Pamięć i miejsce. Perspektywa społeczno-edukacyjna (s. 207-221). Gdańsk: Wydawnictwo Uniwersytetu Gdańskiego.

Nora, P. (2001). Czas Pamięci. Nowa Res Publica, 7, s. 37-43.

Pilch, T. (2019). Miejsce, przestrzeń i czas w historii rodziny. W: M. Mendel, W. Theiss (red.), Pamięć i miejsce. Perspektywa społeczno-edukacyjna (s. 131-150). Gdańsk: Wydawnictwo Uniwersytetu Gdańskiego.

Sass, M. (2019). Kamnitzer Wald - las w przestrzeni pamięci i edukacji. W: M. Mendel, W. Theiss (red.), Pamięć i miejsce. Perspektywa społeczno-edukacyjna (s. 131-150). Gdańsk: Wydawnictwo Uniwersytetu Gdańskiego.

Smith, A.D. (2005). Myths and Memories of The Nations. Oxford: Oxford University Press. 
Snyder, T. (2017). O tyranii. Dwadzieścia lekcji z dwudziestego wieku. Kraków: Znak Horyzont.

Terciak, P. (2019). Fenomenologia nie-miejsc pamięci. Na granicy getta Litzmannstadt. W: M. Mendel, W. Theiss (red.), Pamięć i miejsce. Perspektywa społeczno-edukacyjna (s. 223-241). Gdańsk: Wydawnictwo Uniwersytetu Gdańskiego.

Zbierzchowska, A. (2019). Przekaz pamięci rodziny wśród gdańszczan pochodzenia wileńskiego. W: M. Mendel, W. Theiss (red.), Pamięć i miejsce. Perspektywa społeczno-edukacyjna (s. 151-162). Gdańsk: Wydawnictwo Uniwersytetu Gdańskiego. 